\title{
Retraction Note: Tumor suppressor microRNA-31 inhibits gastric carcinogenesis by targeting Smad4 and SGPP2
}

\author{
W. Ruoming $\cdot$ Y. Zhen $\cdot$ Z. Tengteng $\cdot H$. Jisheng
}

Published online: 5 April 2021

(c) The Author(s), under exclusive licence to Springer Nature America, Inc. 2021

Retraction to: Cancer Gene Therapy

https://doi.org/10.1038/cgt.2015.41

Published online 23 October 2015

The Editor-in-Chief has retracted this article because figures $1 \mathrm{~b}, \mathrm{~d}, 3 \mathrm{a}, 4 \mathrm{~b}, 5 \mathrm{~b}, \mathrm{~d}$ and e, 6a, b, c, as well as parts of the text were duplicated from a previously published article by Bao et al. [1]. In addition, the article shows significant overlap with an article by Tian et al. that was simultaneously under consideration [2] and another previously published article by $\mathrm{Wu}$ et al. [3].

The authors have not responded to correspondence regarding this retraction.

\section{References}

1. Bao Y, Chen Z, Guo Y, Feng Y, Li Z, Han W, et al. Tumor Suppressor MicroRNA-27a in Colorectal Carcinogenesis and Progression by Targeting SGPP1 and Smad2. PLoS ONE. 2014;9: e105991. https://doi.org/10.1371/journal.pone.0105991.

2. Tian K, Di R, Wang L. MicroRNA-23a enhances migration and invasion through PTEN in osteosarcoma. Cancer Gene Ther. 2015;22:351-9. https://doi.org/10.1038/cgt.2015.27.

3. Wu XL, Cheng B, Li PY, Huang HJ, Zhao Q, Dan ZL, Tian DA, Zhang P. MicroRNA-143 suppresses gastric cancer cell growth and induces apoptosis by targeting COX-2. World J Gastroenterol. 2013;19:7758-65. 